\title{
DOCUMENTÁRIO
}

\section{COMÉRCIO E CONTRABANDO ENTRE A BAHIA E POTOSI NO SÉCULO XVI $\left({ }^{\star}\right)$}

A correspondência do Cardeal-Infante, vice-rei de Portugal, com Filipe II em 1586 contém três importantes cartas concernentes ao Brasil; a mais interessante, que é publicada in extenso (1) a seguir, trata do comércio de Buenos Aires e de seus vizinhos nos seguintes têrmos:

"...E asy me parece serviço de Vosa Magestade corer o comercio que se "ora començou com os da cidade de Boynos-Ayres do Rio da Prata, e que. se "enuyen aquelas partes os Padres da Companhia que Dom Francisco de Vito"ria, bispo de Tucumão $|. .$.$| para naquele bispado aiudar a promulgar o$ "Evangelho, e se escriva ao gobernador e ao visitador dos Padres que residem "naquelas partes os mande temdo com ista cydade toda a boa carrespondemcia, "e que Vosa Majestade mande agradecer a Salvador Correa, capitão do Rio de "Janeiro ser o primero que abrio este caminho, e que da prata que este bispo "mandou ao governador lhe deve Vosa Magestade hazer merçed como pede "por the ser mandada na forma que Vosa Magestade mandara ver por sua carta..."

A propósito dêste documento de fonte portuguêsa que anexamos a um trabalho formado até agora de peças de arquivos espanhóis, desejaríamos ajuntar alguns esclarecimentos sôbre o alcance para - Perú dessa abertura ao tráfego do Rio da Prata. O comércio português nessa região nos séculos XVI e XVII foi estudado recentemente pela Professôra Alice Piffer Canabrava (2); quem quer que se ocupe da história econômica da América do Sul deve se referir de agora em diante a êsse trabalho claro, denso e sólido. Graças a essa exposição, a seqüência dos fatos está bastante conhecida para esclarecer o primeiro aspecto marcante dêsse texto, a mistura heteróclita do comércio com o Evangelho, e será suficiente recordá-los ràpidamente. $\mathbf{A}$ informação dada pelo Cardeal é visìvelmente vaga, embaraçada e, com a leitura, as questões surgem: qual a novidade dêsse caminho que acaba de ser aberto? Que comércio se fazia pôr êle? Entre que pontos extremos? Em favor de que vantagens, contra que interêsses, êsse arrazoado?

(*). - Texto francês traduzido pelo Lic. Paulo Pereira de Castro.

(1). - Archivo General de Simancas:- Secretarias Provinciales, libro 1550, f.o 320.

(2). - PIFFER CANABRAVA (Alice) - $O$ comdrcio portuǵuês no Rio da Prata (1580-1640). Separata do Boletim de História da Civilizaçăo Americana n.o 2, da Faculdade de Filosofia, Ciências e Letras da Universidade de São Paulo. São Paulo, 1944. 4 cartas, $X V-+174$ pp. in-8.. 


\section{O Bispo de Tucuman, Francisco de Vitória.}

As relações dos portuguêses do Brasil com os castelhanos do Perú começam pouco depois de 1580; êste ano marca no Velho Mundo a união das corôas de Portugal e da Espanha; os vastos territórios conquistados no Novo Mundo pelos poyos ibéricos são submetidos a um único cetro. No plano político os portuguêses haviam obtido pelas Capitulações de 1580 , que os dois Impérios continuassem a ter vida separada; mas pôr tôda a parte em que havia vizinhança, estabeleceram-se relações comerciais. Na América do Sul, 1580 é a data da segunda fundação de Buenos Aires. A conjuntura favorável foi decidida por um homem da Igreja que não pôde renunciar a ser o melhor homem de negócios de seu tempo no Novo Mundo. Foi êle quem abriu caminho às trocas comerciais entre o Brasil e o Perú. Se o papel de Salvador Corrêa nos continua desconhecido, Francisco de Vitória deixou traços bastante nítidos, apesar de lacunas e contradições de pormenores, para que possamos conjecturar sôbre o conjunto de suas atividades.

Francisco de Vitória (3) era um comerciante português que tardiamente ingressou na ordem dos Dominicanos em Lima; nomeado procurador de sua ordem, em Madrí e em Roma, soube aatrair as boas graças do Papa Pio V e de Filipe II, do qual obteve o bispado de Tucuman em 1577 (4). Ao chegar, em 1581 (5), decepcionou-se com a sua diocese: a governadoria das provincias de Tucuman, das Jurias e das Diaguitas era enorme; sua superfície cobria as províncias de Salta, Jujuy, Catamarca, La Rioja, Tucuman, Santiago del Estero e Cordoba, da Argentina atual. Mas a parte efetivamente ocupada era insignificante: quatro cidades apenas São Miguel de Tucuman, Santiago del Estero, Talavera e Córdoba; repartiam-se os espanhóis por grupos de vinte e cinco, quarenta ou cinqüenta "vecinos"; na realidade essas cidades escalonadas ao longo do caminho que subia para o Alto-Perú, eram pequenas aldeias cercadas pelos campos cultivados pelos índios das "encomiendas". A planície, uma estepe coberta de arbustos secos e espinhosos, era o domínio de milhares de guerreiros selvagens. Nenhuma mina na parte montanhosa, árida e inabitada. Nos vales vivia-se patriarcalmente dos produtos do solo que eram mercadejados no local; plantava-se algodão ou cortavam-se árvores na floresta; as únicas indústrias eram as de tecidos grosseiros que se vendiam nos cen-

(3). - Sôbre Francisco de Vitória vide bibliografia in LEITE (Serafim), S. J., História da Companhia de Jesús no Brasil. Lisboa, 1928, 2 tomos in-8.o, $610-+700$ pp. Tomo I, p. 346, nota 1; PIFFER CANABRAVA (Alice), loc. cit., Cap. VI. Sóbre o curriculum vitae de Fransisco de Vitória vide LOZANO (P. Pedro), História de la Compania de Jesús en la Provincia del Paraguay. Madrid, 1754, Tomo I, Cap. VIII, pp. 33-40; LEITE (Serafim), loc. cit., I, p. 344; PASTELLS (P. Pablo), Historia de la Compania de Jesús en la Província del Paraguay. Madrid, 1912, Tomo I, p. 49, nota I.

(4) . - Acêrca de sua nomeação para o bispado de Tucuman, vide PASTELLS, loc. cit., p. 9, n.o 8 .

(5). - LOZANO, op. cit., loc. cit. 
tros mineradores da Cordilheira e, em San Miguel de Tucuman, a de carretas, as famosas carretas da Argentina colonial, fabricadas inteiramente de maneira, sem uma única peça de ferro. $\mathrm{E}$ o bispo a queixar-se ao rei: nem clero, nem recursos; dispunha de quatro a cinco padres para uma população que êle avaliava, não sem exagêro, em 100.000 almas; os dízimos, dos quais deveria viver, não chegavam a quinhentos pesos; quanto aos quinhentos mil maravedis dos quais Sua Majestade lhe havia feito mercê, êle não sabia de onde os tirar. Pediu sua demissão (6).

Mas; quando ia ao terceiro Concílio de Lima, em.1583 (7), deteve-se nos altiplanos andinos, na região das minas de prata: se Tucuman não era rica como seria de desejar, as províncias vizinhas o eram e, colocada a meio caminho entre o Alto-Perú e o Atlântico, sua posição estratégica era excelente. Francisco de Vitória começou por enviar seu coadjutor; o diácono Salcedo, ao Brasil, para pedir religiosos ao Provincial da Companhia de Jesús (8); o mensageiro era também portador de uma carta e de uma soma em dinheiro para o governador Manuel Teles Barreto (é nesse momento que se situa a informação do vice-rei). E, de volta da capital, êle solicitou e obteve da Audiência de Charcas úma licença para importar escravos negros, para seu serviço pessoal, pelo Rio da Prata (9). Tendo voltado também com uma resposta afirmativa, Salcedo foi de novo mandado ao Brasil, em 1585, para buscar uns e outros, em missão de reabastecimento espiritual e temporal. Embarcou provido de vultosa quantia em dinheiros, em um barco comprado por quatro mil pesos pelo bispo; partiu de Santa Fé ou de Buenos Aires (há testemunhos para um e outro local e chegou à Bahia, remontando ao longo da costa (10), com uma parada de vinte e seis dias em São Vicente; era o primeiro barco que partia das possessões espanholas para navegar rumo ao norte do Rio de Janeiro, contando sòmente com recursos locais. Causou sensação e a expedição foi seguida com vivo interêsse. Acolhidos na Bahia pelo governador, cuja boa vontade fôra muito bem cultivada, cheios de presentes por sua vez, os enviados do bispo, precisaram comprar por mil ducados um segundo barco de trinta ou quarenta toneladas. Após uma permanência de seis meses, os dois barcos voltaram carregados com seis jesuitas, oitenta escravos negros (alguns falaram em cento e cinqüenta), comerciantes, mercadorias (livros, medalhas de estanho, relíquias, estátuas, sinos, - de um lado - e tecidos "para mais de cem mil ducados", conservas alimentícias, pontas de arados, caldeiras de co-

(6). - PASTELLS., op. cit., I, p. 25, nota 21.

(7) . Ibidem, nota 20

(8). - LEITE, op. cit., p. 344.

(9). - LEVILLIER (Roberto), Audiencia de Charcas. Correspondencia de presidentes $y$ oidores. Documentos del Archivo de Indias, 3 tomos. Madrid, 1918-22, Tomo II, p. 319.

(10). - LEVILLIER (Roberto), Correspondencia de los oficiales de Hacienda del Rio de la Plata con los Reyes de Espanta, Madrid, 1915, XV+535 pp., I, p. 376; PIFFER CANABRAVA (Alice), op. cit. 
bre, utensílios e ferro bruto, - de outro). No Espírito Santo, o governador local, Miguel Vasco Fernandes Coutinho, aproveitou a ocasião, nos dizem, para enviar um presente de dois mil pesos a sua irmã, a mulher de Ruano Tellez, o Procurador ("Fiscal") da Audiência de Charcas; a estadia prolongou-se por vinte e dois dias. No Rio de Janeiro, onde demorou-se outro tanto, carregou-se um outro presente importante, conservas e barris de gengibre, oferecido ao bispo pelo seu amigo, o capitão Salvador Corrêa de Sá. Em São Vicente, fizeram-se provisões de viagem: conservas, farinha de mandioca e cem quintais de arroz (ou seja quatro mil e seiscentos quilos). Após essa navegação sem pressa - nove meses de escala em quinze de ausência - entraram ao amanhecer no Rio da Prata; aí, tiveram um mau encontro: o pirata inglês Robert Withington penetrava no estuário para apanhar água doce. As relíquias foram jogadas nágua, as mercadorias pilhadas, os barcos levados para o sul, depois abandonados sem velas e sem provisões; tripulação e passageiros, entre os quais quarenta e cinco negros que os inglêses não quizeram, chegaram a Bueno Aires, famintos e em farrapos (11). A aventura provocou enorme ruído, Os inimigos de Francisco de Vitória - seu caráter cúpido e disputador grangeara-lhe muitos denunciaram ao rei e ao Conselho das Índias êsse bispo negreiro que transformava seu bispado em feitoria (12). Elle teve fiéis defensores entre os jesuítas que, realistas, conheciam o preço de uma missão e que também exerciam atividad̦es temporais, condição essencial de seu apostolado (13); êles salientaram seu zêlo e seus costumes irrepreensíveis, mas não impediram que os negros levados a Potosi fôssem apreendidos junto com as récuas de mulas e rebanhos de vacas trazidas de Tucuman; foi aberto um inquérito para se saber a forma como fôra utilizada a licença de importação e sôbre o pagamento dos diferentes direitos e taxas de entrada dos quais o bispo de Tucuman não havia conseguido exonerar:se (14). Francisco de Vitória não desanimou; sabe-se ainda que logo que pôde enviou ao Brasil, pelo mesmo caminho, um carregamento de tecidos de Tucuman trazidos de Córdoba em carretas; em 1588 um de seus barcos, carregado com quarenta e cinco mil pesos de prata, em viagem para o Brasil perdeu seu carregamento.

Mas sua agitação e seu gôsto pela luta, mais ainda do que suas traficâncias, haviam-no posto mal com seu arcebispo, São Toríbio de Mongrovejo, e os altos funcionários da Audiência de Charcas (15). Tornando-se indesejável, sua demissão foi aceita. Ficou ainda alguns meses em Potosi e finalmente voltou para morrer na Espa-

(11). - LEVILlIER, op. cit.; PIFFER CANABRAVA, (Alice) op. cit.

(12). - PASTELLS, op. cit., I, p. 50

(13). - Ibidem, I, 48, 53. Acêrca da sua defesa por todos os historiadores antigos da

Companhia, vide principalmente LOZANO, op. cit.

(14). - Sôbre a apreensáo dos negros levados a Potosi e a abertura de inquérito cf.

(15) . - Ibidem. 
nha, no convento de Atocha, em Madrí, deixando no pôrto de Buenos Aires "uma grande organização para os negócios que se podem fazer entre o Brasil, esta governadoria e o vice-reinado do Perú".

\section{II. - Pelo Rio da Prata.}

Era mesmo do Perú e do Brasil que se tratava, quando Francisco de Vitória fretava barcos, oferecia esplêndidos presentes às autoridades e grangeava a poderosa amisade da Companhia. Em suas disputas com o governador de Tucuman, o bispo sustentou ante o rei que êle havia sido o primeiro a servir-se do caminho do Rio da Prata para ir ao Brasil: "descubrir, abrir el camino del Rio de la Plata hasta Viaza y de alli al Brasil", a expressão reaparece a cada instante na pena dos contemporâneos quando evocam a figura do bispo de Tucuman (16). Que significa isso?

No sentido próprio, não houve descoberta alguma: o Rio da Prata e seus afluentes já haviam sido explorados e eram bastante bem conhecidos em suas linhas gerais. Mas nenhuma circulação regular de intercâmbio animava a grande via fluvial. As cidades continentais de Tucuman e as cidades fluviais do Rio da Prata tinham vidas voltadas sôbre si próprias: isolovam-se em dois mundos separados. Em Tucuman não havia com que alimentar uma economia intensa: o mesmo acontecia nas províncias do Rio da Prata. Junto a foz, Buenos Aires vegetava sem participar do comércio que animava o conjunto das vias de comunicação do Vice-Reinado do Perú.

Em terra, a rêde de estradas permanecia a mesma do tempo dos incas, paralela aos dois lados da espinha dorsal do continente, a alta cadeia costeira da Cordilheira; sua chave eram os dois caminhos pré-colombianos que ligavam o Norte ao Sul para permitir o rápido deslocamento das fôrças armadas de um extremo a outro do Império; um, o dos "llanos", percorria as costas do Equador ao Chile; o outro, o dos incas, acompanhava o corredor interandino, os vales longitudinais que aí são as vias naturais de penetração; tendo por centro Cuzco, a capital do Tawantisutyu, êle ia ter a Pasto e Quito no norte, e, ao sul, seguia as margens do Titicaca, prosseguia pelos altiplanos, chegava a Chuquisaca e, após descer até Tucuman, atravessava mais uma vez a Cordilheira para chegar ao Chile onde fazia junção com o caminho do litoral (17). Essas estradas estratégicas eram ligadas por caminhos secundários que lhes eram perpendiculares e pelos quais se trocavam os produtos de regióes de climas diferentes. No mar, a navegação dos espanhóis, paralela também à costa, seguia o itinerário histórico dos conquistadores, do istmo do Panamá a Lima, a nova capital que havia suplantado a con-

(16). - PIFFER CANABRAVA, (Alice), op. cit..

(17). - LOPEZ DE GOMARA (Francisco), Historia general de las Indias, Madrid, Calpe, 1941, 2 tomos. T. I, cop. IXXXIX. 
tinental Cuzco. Era em seu pôrto, Callao, que a Frota do Mar do Sul trazia das feiras de Pôrto-Belo, de volta e em troca da prata das minas, as mercadorias enviadas da Europa por Sevilha e pela "Casa de la Contratación de las Indias". A cabotagem repartia-as pelos pequenos portos de onde penetravam no interior pelos caminhos que atravessavam a Cordilheira. Dêsses caminhos, o de Lima aos altiplanos, tinha, com a exploração das minas, uma atividade extraordinária .

Os altiplanos eram ao mesmo tempo a região mais afortunada e a mais desherdada do Perú. Sua altitude média de três a quatro mil metros torna o clima glacial, o ar rarefeito e a terra estéril. A partir de 1545, a descoberta dos filöes argentíferos de Potosi, os mais ricos do mundo, tornou a região a mais povoada da América do Sul. Houve um afluxo vertiginoso para êsse local; uma cidade cogumelo surgiu nessas paragens desoladas, a 3960 metros de altitude. A Vila Imperial de Potosi, em 1574, possuia mais de 120.000 habitantes: era a aglomeração mais populosa e mais rica do continente austral. O abastecimento dessa turba no deserto fazia vir os produtos do. Novo e do Velho Mundo; o lago Titicaca para aí expedia seu peixe congelado, sua batata, seu "charqui" (carne sêca de lhama); os vales, o milho, frutas e produtos tropicais; os Andes, a coca; Cuzco, conservas; Quito, tecidos grosseiros; o Chile, couros e o sebo para velas; estas últimas importações chegavam pelo pôrto de Arica, destinado pelo vice-rei Francisco de Toledo ao serviço da indústria metalúrgica dos centros mineiros dos altiplanos. As vias pré-colombianas traziam assim para o Alto Perú os produtos locais, "da terra", gêneros agrícolas, tecidos grosseiros, produtos artezanais indígenas, tôdas elas, mercadorias pesadas, volumosas, mas de relativo pequeno valor. Lima enviava artigos da Europa adquíridos pelos seus comerciantes nas feiras do Istmo. Eram produtos de luxo, vinhos, tecidos principalmente, mas também uma grande parte do necessário à vida cotidiana; utensílios, instrumentos de trabalho, armas, ferro, chumbo, aço, cobre - cujo fornecimento a Espanha reservava para suas províncias de além-mar.

Todo o aparelhamento para Potosi era transportado por animais cargueiros, lhamas e mulas. A Cordilheira Ocidental cai sôbre - Pacífico em declives muito abruptos; a distância em linha reta é quintuplicada pelo caminho, verdadeira trilha de mulas que serpenteia em busca de pastagem para a noite ou da ponte de caniços que permitirá atravessar a torrente. Não houve nenhum caminho carroçável na Cordilheira ou nos altiplanos antes do século XX.

Se se considera o comprimento do trajeto percorrido pelos produtos da Europa, os itinerários expostos aos ataques dos piratas no mar, dos selvagens em terra, a diversidade dos meios de transporte, os inúmeros transbordos, a quantidade de mercadoria perdida ou deteriorada, os impostos, as taxas alfandegárias impostas à saída e à entrada, o lucro dos negociantes das feiras de Pôrto-Belo que ti- 
nham por princípio marcar seus preços pelo dobro dos da Europa, o ganho de todos os intermediários - não será de surpreender que os preços subam na mesma ordem de grandeza que a altitude de seu suntuoso mercado de consumo. De uma forma geral, a vida era muito cara nas Índias e nelas. Potosi era o mercado mais caro. A minoria riquíssima dos exploradores das minas podia pagar todos os produtos necessários ou supérfluos. Mas essa opulência era excepcional. As regiões desprovidas de metais preciosos viviam na miséria. Era o caso das províncias de Tucuman e do Rio da Prata que não podiam participar das feiras de Pôrto-Belo, onde o ouro e a prata constituiam o principal elemento das transações entre as colônias e a metrópole. Nenhum comerciante descia para vender em Tucuman ou no Rio da Prata ou, se vinha algum por espírito de aventura, seus preços eram exorbitantes. O relato das tribulações do primeiro barco de Francisco de Vitória ilustra bem essa situação: com efeito, nos é dito aí que "a desolação e a decepção foram grandes em Buenos Aires ao receberem os sobreviventes, porque os habitantes contavam com o carregamento trazido do Brasil para abastecerem-se de roupas e de ferramentas que lhes faziam falta". Os artigos oriundos da Europa não podiam ser adquiridos senão trocando-os em Potosi por seus produtos in-natura: vinhos locais, madeira, tecidos. Também os preços excessivos das mercadorias de Castela eram objeto das queixas que reaparecem a cada momento na correspondência das províncias.

Foi um dos problemas com que defrontou a Audiencia de Charcas desde que ela foi criada (1561); êle se manteve até o fim do século. A primeira condição para uma política de abaixamento de preços seria romper a subordinação econômica ao monopólio de fato exercido pelos homenś de negócio de Lima; para isso seria necessário encontrar-se uma rota comercial para ir e vir da América para a Espanha que fôsse menos longa, menos custosa, menos perigosa que a do Panamá; seria necessário achar uma saída do altiplano para leste, estabelecer comunicação entre a vertente oriental da Cordilheira e um pôrto do Atlântico (18).

Para determinar o ponto de saída na costa, os reconhecimentos tactearam por uma vintena de anos; grosseiramente, os traçados podem resumir-se a dois: um, o mais curto, direto pelo norte e pelo Paraguai; o outro, descia para o sul até o Rio da Prata; êles eram conhecidos, mas pouco frequientados. Quando Francisco de Vitória quis mandar uma carta para o Brasil, foi-the necessário enviá-la por correio especial; nessa ocasião êle adotou o itinerário que atravessava o Chaco (19), transpunha o rio Paraguai em Assunção, ganhava o rio Paraná, subia-o até alcançar terra entre as confluências do Iguaçú e do Pequiri, de onde se continuava atravessando a região costeira, o "Viaza" de nossos textos, para terminar na Lagoa dos Patos.

(18). - MATIENZO (Juan), Gobierno del Perú, Buenos-Ayres, 1910, cap. XV.

(19). - LOZANO, op. cit., pp. 21-26; LEITE (Serafim), op. cit., p. 344. 
Era um velho caminho pré-colombiano pelo qual os povos indígenas se comunicavam com o mar e com as regiões do ocidente; a oeste do Paraná, o caminho continua e alcança o Perú e a costa do Pacífico. $\mathrm{Na}$ sua primeira parte, era o itinerário traçado pelo adelantado Álvaro Nuñez Cabeza de Vaca em 1541 em sentido inverso quando, partindo de Espanha com três barcos, chegou a Cananéia e estacionou em Santa Catarina; dividiu então sua comitiva em duas, uma tomou a rota do mar para Buenos Aires; e à frente da outra, êle ganhou Assunção por terra e pelo rio. A região era o ponto de encontro dos portuguêses que desembarcavam no continente americano e dos espanhóis que refluiam do interior para a costa; por muito tempo o limite de suas respectivas possessões variou. $\mathrm{Em} 1580, \mathrm{Ca}$ nanéia marcava o ponto extremo do avanço português. Para fazer as duzentas léguas do Paraná à costa, eram necessários três meses na ida e um mês e meio na volta, porque então descia-se a corrente fluvial (20). Mas essa rota, relativamente curta e direta, oferecia o inconveniente de atravessar vastas regiōes não colonizadas; sem insistir no Chaco, os espanhóis não haviam estabelecido senão uma aglomeração no Viaza, perto do mar - São Francisco. O Paraguai contava apenas duas cidades - Assunção e Ciudad-Real e não chegara a estabelecer comunicações com o exterior ("a comunicarse con otros") (21). A tentativa do diâcono Salcedo, enviado em 1585 para reconhecer o caminho, deve ter sido concludente: sob pretexto de que o bispo do Paraguai desviaria santamente os jesuítas para o serviço de suas próprias ovelhas, Francisco de Vitória thes fêz tomar outro caminho (22).

Erá um caminho muito mais longo. Confundia-se com o caminho inca, na descida da Cordilheira Oriental para Tucuman. Aí, a exploração havia hesitado; sucessivamente, o govêrno do Paraguai e a Audiência de Charcas, procurando realizar o plano de penetração traçado pelo ouvidor Juan Matienzo, desde 1566, haviam tentado drenar a vertente da cadeia que desce escalonadamente para as bacias amazônica e platina por uma via fluvial que seria um dos afluentes da margem direita do Paraná, o Pilcomayo, o Rio Bermejo ou o Salado, mas foi necessário renunciar a êsse projeto porque êsses rios foram julgados muito irregulares, atravancados por areia e por vegetação tropical. Foi pois um estrada terrestre que foi escalonada com cidades de pouso e de defesa; ela passava por Santiago del Estero, contornava os pântanos até Córdoba e alcançava $\mathrm{O} \mathrm{Pa}$ raná a vinte léguas de Tucuman, em Santa Fé, de onde se descia de barco até Buenos Aires. Muitos espanhóis subiram ao longo do rio em sentido inverso para chegarem às minas de Potosi no Perú (23); mas ir de Buenos Aires até chegar ao Oceano e sem jamais perder

\footnotetext{
(20). - LOPEZ DE GÓMARA (Francisco), op. cit., T. I, cap. LXXXIX.

(21). - MATIENZO (Juen), op. cit., cap. XV.

(22). - LEITE (Serafim), op. cit., T. I, p. 344 e p. 346, nota 1; PIFFER CaNABRAVA (Alice), op. cit., cap. VI; LOZANO (P. Pedro), op. cit., T, I, cap. VIII, pp. 33-40; PASTELLS (P. Pablo), op. cit., 49, nota 1.

(23). - LOPEZ DE GOMARA (Francisco), op. cit.
} 
de vista a costa, chegar até a Bahia, o que não tinha sido até então mais do que uma hipótese, foi realizado por Francisco de Vitória. As imensas vantagens comerciais do caminho compensavam a extensão geográfica. Ao longo da estrada de mulas da descida da CordiTheira, os tambos criados pelos incas continuavam a oferecer abrigo e alimento para animais e pessoas. A fundação de Jujuy defendia o caminho contra os temíveis índios chiriguanais. Na planície, à beira dos rios, viviam índios pouco numerosos, a maior parte dos quais era pacífica e hospitaleira; no litoral Matienzo enumera complacentemente as escalas: Puerto San Rodrigo, Santa-Catarina, São Francisco, Cananéia, depois em território brasileiro: São Vicente, São Sebastião, Angra dos Reis, Rio de Janeiro, Cabo Frio, Bahia Grande, Espírito Santo e enfim a Bahia de Todos os Santos. Essa navegação permanece costeira, é uma rota de cabotagem que permite o comércio - não é nečessário renovar a água e os víveres que o clima tropical corrompe ràpidamente? Não é senão a partir do Cabo de Santo Agostinho (24) que ela se aventurará a tornar-se transatlântica para ganhar as Canárias e aí reunir-se à rota das frotas e dos galeôes para Sevilha.

\section{III. - Primeiras trocas.}

Que mercadorias Francisco de Vitória lançou no trajeto comercial assim reconhecido como o mais vantajoso? No sentido de descida um único produto poderia ser oferecido para trocas: a prata cobiçada por todos. Para a subida, a corrente que animou a nova artéria desenvolveu 'de passagem a atividade das províncias de Tucuman e do Rio da Prata, mas, sobretudo, ela deu início a um tráfico com o Brasil, a colônia vizinha.

A prata enviada pelo bispo não poderia evidentemente ter sido obtida em Tucuman. Por outro lado, em Potosi, ela era extremamente abundante, naqueles anos, novo elemento favorável na conjuntura. Após o incremento dos quinze primeiros anos, os filões pareciam esgotados por uma exploração desordenada e cheia de desperdício, entregue ao empirismo dos indígenas, quando o quinto vice-rei do Perú, Francisco de Toledo tira do marasmo a "Vila Imperial". Ele criou, a partir de 1570, nos altiplanos a grande indústria metalúrgica do metal branco. Impôs em Potosi uma técnica de grande rendimento: o amálgama que permite retomar e tratar restos de minérios rejeitados até então; pôs em vigor o monopólio real da produção e da venda do mercúrio da mina de Guancavelica a trezentas léguas dali, organizou seu transporte para os altiplanos; dotou os moinhos de minério da fôrça motriz hidráulica fornecida por dezessete reservatórios escalonados na montanha; o serviço de trabalho forçado que era adstrito aos índios, a famosa "mita", foi reorganizado de maneira a proporcionar todos os anos treze mil trabalhadores aos quais se

(24). - MATIENZO (Juqn), op. cit., cap. XV. 
somavam outros tantos operários livres (25). Esse dispositivo, depois'de alguns anos de ajustamento e de experiência, começava a produzir seus efeitos e o rendimento vinha sendo crescente. Nada de mais eloqüente a êsse respeito do que o montante do "quinto": o Teșouro arrecadava vinte por cento, seja a quinta parte da produção de prata: de 325.467 pesos em 1570 , o quinto passou a 1.526 .455 pesos em 1585, montante em tôrno do qual êle se manteve até a primeira década do século seguinte, que marca o ponto de partida de nova crise na produção (26). O quintuplo dessa quantia representa a produção declarada aos funcionários da Caixa Real encarregados de arrecadar o impôsto, mas como é necessário contar ante uma fiscalização excessiva, para ter-se uma idéia da produção total, precisa-se aplicar uma correção a êsse produto. Sabe-se que grande parte da produção escapava ao contrôle e evitava o impôsto muito pesado.

Ao lado dos "azogueros" que elaboram o mineral nos "patios" de seus moinhos, subsistia uma produção artezanal relegada ao indígena. Os "guayras" (27), os fornos de barro da técnica incaica sobreviveram por muito tempo ainda, menos numerosos evidentemente do que no tempo em que Cieza de León (28) viu os altos de Potosi flamejarem com seis mil fogos. Os índios serviam-se também do amálgama nos moinhos grosseiros, os "trapiches" para tratar os resíduos ou o mineral roubado; o índio tinha o privilégio oficialmente reconhecido por Francisco de Toledo, de rescatar, de vender o mineral que êle acabava de tirar do fundo da mina, o melhor, bem entendido, às mulheres que os esperavam à saída, em troca de água fresca ou de "chicha", a aguardente de milho, ou de alimento; as "pulperias", os bazares, aceitavam também êsse modo de pagamento. Parece que essa era uma maneira de interessar o trabalhador em produzir antes de mais nada um complemento a um salário excessivamente baixo.

Os espanhóis tinham a sua disposição numerosos processos de fraude fiscal que podiam combinar entre si: transportar o minério para centros mineradores pobres onde a arrecadação do rei não passava de dez por cento. Serviam-se de mercúrio subtraído ao monopólio real que o fornecia ao dobro do preço de custo; o tráfico do mercúrio de contrabando era muito ativo: o comerciante descia ao fundo da mina de Guancavelica para comprá-lo diretamente aos

\footnotetext{
(25). - CANETE Y DOMINGUEZ (Pedro Vicente), Guia histórica, fisica, politica, civil y legal del Gobierno y Intendencia de la Provirtia de Potosi y sus partidos, Potosi, 1952, $900 \mathrm{pp}$. 20X 12,20 lam., I carta geog., Introde. y notas de Armando Alba, cap. I ao VI.

(26). - SOETBEER (Dr. Adolf), Edelmetall-Produkition und Werthverhältniss Zwischen Gold und Silber seit der 'Entdeckung Amerika's bis zur Gegenwart. 141 pp. in.4. Ergänzungsheft n.0 57 zu "Petermann's Mitteilungen". Gotha, Justus Perthes, 1879.

(27). - Sôbre a técnica incaica de metalurgia da prata vide RIVET (Paul) et ARSANDAUX (H.), La métalurgié en Amérique précolombienne. Paris, 1946, 254 pp. 8 figs.. Travaux et mémoires de 1'Institut d'ethnologie de l'Université de Paris, $t$. XXXIX.

(28) . - CIEzA De León (Pedro de), La crónica del Perú, cap. CiX.
} 
índios; êle desaparecia durante seu transporte por terra e por mar para os armazens reais de Chincha ou de Arica. Em Potosi, não havia meio de se controlar a quantidade de prata que podia ser produzida com uma determinada quantidade de mercúrio, porque os azogueros sustentavam que o rendimento era variável segundo a qualidade do mineral e a experiência ou habilidade do operador. A fabricação podia ainda ser interrompida no estado da "pinha" quando a prata saía do forno cujo calor tinha feito evaporar o mercúrio; - metal branco se apresentava então sob a forma de uma bola cônica, de um pequeno pão de açúcar, de uma pinha. Eram necessảrios duas pinhas para fazer um lingote, mas havia uma eterna falta de meios de pagamento no Perú; a "pinha" não se tornavá jamais barra, ela circulava, escapando à pesagem, à titulação e à marcação que acompanhavam a retirada do "quinto". Enfim, era perfeitamente possível obter o sursis do "quinto", e, uma vez lançado na circulação, o rei não se reapoderaria mais do lingote.

Os autores antigos e modernos avaliam essa produção paralela em um montante eqüivalente ao da produção oficial, de sorte que para ter sua ordem de grandesa, seria necessário decuplicar o montante do "quinto"; isso fica evidentemente a cargo da imaginação de cada um: não. há nenhuma maneira de determinar qual terá sido a produção de prata que foi derramada no mundo nos grandes dias de Potosi.

A prata não quintada transformava-se sob o nome de plata labrada em objetos de igreja, em joalheria, em baixela chata dessa prataria colonial espanhola de um cinza de chumbo tão característico que era usada nas aplicações mais vulgares da vida quotidiana (29).

Pinhas e lingotes, quintados ou não, serviam de meios de pagamento; até o fim do século XVIII, a falta de numerário fêz do Perú um país de barganhas em que a prata era mercadoria. A "Moeda" de Potosi não tinha combustivel apropriado para a sua cunhagem e suas peças eram conhecidas por sua baixa qualidade. Além disso, - preço de custo elevado do metal branco em barra (devido ao "quinto" e ao preço do mercúrio) fazia recuar ante as taxas suplementares de cunhagem .

Devidamente quintados e marcados, os ligotes serviam para o pagamento dos altos funcionários, o vice-rei inclusive; são êsses tijolos de prata que êles empilhavam debaixo da cama tendo em vista o pagamento a que lhe condenará o juicio de Residencia, na prestação de contas após o desempênho de um cargo. Os pagamentos fracionários, na falta de moedas de cobre, se fazia em fragmentos de prata não quintada e em pedaços de moedas cortadas (plata macuquina). A prata não quintada tinha suas cotações e seu mercado negro; ela saldava as aquisições que escapavam ao contrôle da $\mathrm{Ca}-$ sa de la Contratación, isto é o contrabando, particularmente o que

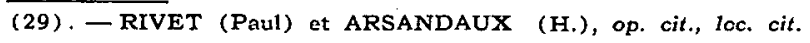


florescia então com as Filipinas e a China. Francisco de Vitória abria para ela nova direção de fuga para o Brasil. Está provado que em 1587 o bispo de Tucuman enviara, por intermédio de seus representantes, 1015 marcos de prata trabalhada que tinham escapado ao quinto real, 215 marcos de prata branca (plata blanca) em lingotes que haviam sido subtraídas à marcação e ouro (30).

A riqueza da jazida e a prosperidade da indústria refletiam em todos os os habitantes de Potosi. Sem nos determos com os índios que, êles próprios, aí viviam menos miseràvelmente do que na Puna, graças aos salários relativamente elevados do trabalho livre, a década 1580-1590 marca a éra das grandes fortunas dos mineradores espanhóis; a média delas ficava entre 300.000 e 6.000 .000 de pesos; a filha do General Pereyra recebera 2.000.000 de pesos de dote. Todos gastavam sem conta. Os cronistas testemunham o luxo que se ostentava por ocasião das festas que se celebravam sob qualquer pretexto: casamento ou funerais de reis, nascimento de príncipe, chegada de vice-rei, procissões, cerimônias cívicas, era tudo sêdas, veludos, brocados bordados de ouro e de pérolas.

Em troca de sua bela prata, que necessidades eram satisfeitas pela nova rota comercial? Os habitantes do Rio da Prata eram então miseráveis. Os produtos de Tucuman, ao contrário, começaram a ter então uma importância crescente; sem falar nos tecidos que serviam para vestir o pessoal de serviço, fixemo-nos no gado que Francisco de Vitória levou para lá: vacas e mulas. Uma estatística de 1610 (31) - posterior de vinte anos à época de que nos ocupamos, mas que pode ser extrapolada, porque ela se refere à mesma fase de prosperidade - fixa o abate anual de vacas em quatro mil cabeças. As mulas que transportavam carga desde Jujuy, esgotadas no ar rarefeito e glacial, mal alimentadas, duravam pouco nos Altiplanos; eram necessárias sessenta mil por ano; sua criação tornou-se a principal fonte de rendas em Tucuman, ao lado da madeira de construção para tôda a maquinária, rodas de moinho e eixos dos pilões.

$\mathrm{Na}$ realidade, Francisco de Vitória preocupava-se pouco com Tucuman; não chegou a passar aí quarenta dias em oito anos (32). Tucuman, como o Rio da Prata, se enriquecerá com a passagem de mercadorias entre Potosi, polo de atração, e o Brasil, terra de abundância, que oferecia seus escravos africanos, ferro, especiarias, conservas e outros produtos de valor.

O comércio intercolonial de Francisco de Vitória nasceu da licença que êle obtivera para importar neǵros para seu serviço pessoal. O pirata inglês lhe havia deixado quarenta e cinco dos que the haviam trazido! Ele os levou para Potosi onde eram tão raros quanto

(30). - PIFFER CANABRAVA (Alice), op, cit., p. 121.

(31). - LIESEGANG (Car1), Deutsche Berg-und Hüttenleute in Süd-und mittel Amerika. Beiträge zur frage des deutschen Einflusses auf die Entwicklung des Bergbaus in Lateinamerika von... Iberoamerikanishen Forsthungsinstitut. Band 19, in 8.0, 120

(32). - PASTELLS, I, p. 45 , notas $27,28,36,37,38$. 
procurados (33). O bispo de Tucuman explica-nos porque, nos motivos de seu requerimento à Audiência de Charcas: "não conseguia encontrar nenhum para seu serviço: eram raros e caros no Perú, porque o comprimento do caminho para chegarem a Nobre de Dios e ao Panamá e de lá a Callao, a subida e o frio nos altiplanos matava mais de metade dêles antes de chegarem a ser postos em serviço" (34). Contràriamente a uma versão tida como certa, não eram empregados no trabalho das minas. O que era possível em Quito com seu clima equatorial, era impossível nos altiplanos batidos de ventos, chuvosos, com geadas tôdas às noites. A experiência havia sido tentada durante o primeiro período de florescimento da exploração de Cerro Rico. Os negros friorentos morriam ràpidamente e seus proprietários sofreram de sua parte uma grande perda de capital. Um negro custava trezentos e cinqüenta a quinhentos pesos, como preço de compra em Potosi; em 1610, vendiam-se, quando muito, uns trezentos por ano. $E^{\prime}$ evidente que nessas condições, a importação de escravos negros não trazia uma solução ao problema da mão de obra nas minas. Os índios constituiam uma mão de obra aclimatada, treinada, econômica (o salário era de quatro reais por dia em 1580 ), sem que fôsse necessário preocupar-se com seu vestuário, alimentação, nem assistí-los em caso de doença ou de acidente. $\mathrm{Na}$ realidade, os negros eram empregados no serviço doméstico, sinal exterior de riqueza que atestava a opulência de seu senhor. Mencionemos que 16 escravos estavam trabalhando nos fornos da Moeda Real.

A importação de ferro oferecia, também ela, um grande lucro: seu consumo era considerável; para a exploração das minas na extração do mineral, o operário, o barretero, servia-se de picaretas e de barras de ferro que se desgastavam muito depressa; no moinho, martelos de ferro pisavam e pulverizavam o mineral. Em 1587, a técnica do amálgama apresentou um progresso: o adicionamento de ferro moído à mistura de mercúrio e de mineral permitia uma economia de mercúrio de mais de um quarto, com melhor rendimento. $\mathrm{Na}$ Vila Imperial, os ferreiros, em 1610 , compravam 44.928 pesos de ferro para ferrar cavalgaduras. Ora, o ferro não faltava no Perú, mas não era explorado para não prejudicar as minas de Biscaia que o forneciam muito caro, tão caro que se pensou em substituí-lo pelo bronze, mas sem êxito. Por essa razão - o fornecimento de ferro a Potosi e à indústria metalúrgica do Alto Perú - que os portuguêses, em duas tentativas, em 1590 e em 1620, pretenderam sem lográ-lo, produzir ferro no Morro de Araçoiaba, a oeste de São Paulo, perto de Ipanema? (35)

Qualquer que fôsse a sua origem, os tecidos eram a mercadoria que se vendia mais fàcilmente na América do Sul. Em Potosi, tam-

(33). - LEVILLIER, Aud. Ge Charcas, II, p. 321.

(34). - LEVILLIER, Aud. de Charces, II, p. 319.

(35). - LIESEGANG (Car1), loc. cit. 
bém nesse setor grande consumidora, em 1620, vinte e quatro lojas de tecidos vendiam cêrca de 625.000 pesos por ano. Quanto a conservas e especiarias, eram gêneros de grande consumo como é natural onde a terra nada produzia; em 1610, vendiam-se cêrca de 3.000 arrobas (33.000 quilogramos aproximadamente), e o mesmo acontecia com o açúcar, com 8.000 arrobas na mesma data.

IV. - Reações e oposições.

Após uma quarentena de anos de planos, projetos e de explorações, a abertura ao tráfico foi realizada pelo Rio de Prata. O itinerário devia ligar o Perú à Espanha por uma via menos longa, menos custosa, menos perigosa que a do Panamá. Mas o objetivo visado foi ultrapassado: as circunstâncias e a iniciativa relegadas aós interêssés de um particular faziam lucrar com elas o país vizinho, Portugal e seu Império Colonial, tanto quanto o vice-reinado; a brecha era muito larga; escapando ao contrôle da metrópole, por ela penetravam mercadorias portuguêsas, brasileiras e africanas. Desde 1588, o presidente da Audiência de Charcas chamàa sôbre isso a atenção do rei explicando-lhe porque interditara tôda relação e todo comércio (tratos y contratos) entre o Rio da Prata e o Paraguai de um lado e o Brasil do outro: "O bispo de Tucuman vangloriava-se de ter aberto a via, o caminho, o tráfico de sua diocese com o Rio da Prata. A meus olhos, ao contrário, êle se desmereceu por fazê-lo sem ter obtido licença de V. M. e por ter mostrado esta entrada para o reino (o Perú) àquêles que não a conheciam; isto será (ou com o tempo poderá vir a ser) uma causa de que o trajeto de Tierra- Firme não seja mais freqüentado" (36).

O resultado do inquérito aberto contra o bispo de Tucuman nos é desconhecido; sem dúvida, após a partida do atrabiliário eclesiástico, o processo teria caído no esquecimento.

Quanto a Buenos Aires, parece certo que a consequiência da abertura de uma saída para o Atlântico manifestou-se amplamente sob a forma de uma baixa de preços, como havia sido previsto pelo auditor Matienzo. Não desejamos outra prova do fato que o caso do ferro. Desde 1588, desenvolveu-se uma reação contra sua importação: o vice-rei proibiu seu uso em mistura com o amálgama, por causa da difícil venda do mercúrio trazido a Potosi pelo monopólio real, pois o processo novo permitia, ao que parece, economizar um

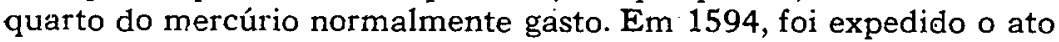
que fechou o pôrto de Buenos Aires ao comércio luso-brasileiro; nos motivos, a importação do ferro é expressamente mencionada três vezes ao lado da dos produtos do Brasil, de Portugal, de Angola e das Índias Orientais... "E. sido informado que por el Rio de la Plata se mete en estas provincias yerro $y$ otras mercaderias del Brasil y pasan otras del extranjero. . . y asi se comienza a frequentar este

(36). - PASTELLS, op. cit., I, p. 48, n. 041. 
paso y porque conviene atajar los daños y inconvenientes que desto siguem..." Sòmente foram autorizados doravante a atracar em Buenos Aires os barcos provenientes de Sevilha e enviados pela Casa de la Contratación.

E' chocante assinalar-se que a exportação correlativa do outro metal precioso, a prata, aue desce de Potosi na volta, não figura entre as razões apresentadas pelo ato. Entretanto, em 1588, os detratores de Francisco de Vitória tinham denunciado ao rei a expedição de 30.000 pesos de prata não quintada. $\mathbf{E}$ o bispo tinha prosseguido; sem falar no carregamento perdido do barco que mencionamos, o que não se teria escondido sob os tecidos de Tucuman que trinta carretas pesadamente carregadas trouxeram a Buenos Aires? Além da perda do quinto, o prejuízo causado ao Tesouro real era patente. $\mathbf{E}$ ' necessário admitir que o enorme volume de ouro e de prata que afluia para Sevilha criava aí uma euforia que permitia fecharem-se os olhos para essas perdas? Mais tarde, quando as remessas baixaram o dano causado aos direitos reais constitui o fundamento expresso das medidas tomadas contra o contrabando.

Dessa vez, parece que os interêsses privados haviam abalado a máquina legislativa. Eles se mostram então muito ativos e obtêm um conjunto de medidas protetoras contra tudo que ameaça o merrado do Perú, quer o perigo venha da China por intermédio das Filipinas e do México. quer do Brasil e de Portugal como no caso presente. Os homens de negócio obtiveram o fechamento do pôrto de Buenos Aires ao comércio estrangeiro. Mas que homens de negócio? Responde-se na mais das vêzes que os de Lima. E' certo que $O$ ato visava a proteção dos interêsses econômicos que se haviam desenvolvido no Perú, enquadrando Buenos Aires no sistema comercial já existente:-a prata que descia dos altiplanos deveria alimentar um grubo de comerciantes poderosos, cujos interêsses se ligaram sempre mais diretamente ao monopólio da via do Pacífico. Mas êsses negociantes de Lima apoiavam-se fortemente sôbre os da península, grandes comerciantes de Burgos e de Sevilha. A Casa de la Contratación, na origem departamento encarregado do comércio do rei com as colônias, transformara-se no órgão do comércio peninsular. Os dois grupos eram estreitamente ligados por uma coligação de interêsses bastante sórdidos. Os da Espanha mantinham relações epistolares regulares com os do Perú e do México, habitualmente seus parentes e amigos. Estavam informados das flutuações dos preços, as altas, as baixas, as vendas, as liquidações ruinosas, a abundância ou a penúria de tal mercadoria; de que convinha carregar a frota esperada. Exprime-se nessa correspondência o interêsse que haveria em retardar a sua partida para provocar o esgotamento dos estoques no mercado. Sevilha ditava os preços e mantinha os colônias crônicamente mal abastecidas. As cartas da América da correspondência de Simon Ruiz, o grande cambista e importador de tecidos de $\mathrm{Me}$ dina del Campo na segunda metade do século XVI, comprovam-no 
(37). Os produtores, os transportadores, os seguradores do ferro de Biscaia teriam apresentado seus veementes protestos ao Conselho das Indias? O fim do século XVI foi a época em que floresceram os asientos, os empréstimos à Corôa concedidos pelos financistas espanhóis e estrangeiros, e o rei não era livre, preso que estava por suas dividas (38).

Os consumidores por seu lado se defendiam: enquanto os habitantes de Buenos Aires protestavam com tôdas as fôrças contra a execução da ordem real, o próprio filho do vice-rei, Garcia Hurtado de Mendoza, então governador de Santa Cruz, reconheceu um dos itinerários do Norte previstos pelo ouvidor Matienzo; mas o adversário estava atento: um ato de 1593 interditou o prosseguimento das expedições de exploração que haviam chegado aos confins do Brasil, por causa da "facilidade com a qual circularia o comércio sôbre êstes caminhos favoráveis". $O$ ato alega razões de Estado para que cada Corôa se atenha a suas conquistas e para interditar uma vez mais as relações entre os que não estão sob sua jurisdição, de acôrdo com as cláusulas políticas das Capitulações de 1580 (39).

De fato, como o ato real salienta, em virtude dos acordos assinados entre o rei e Pedro Gomez Reynel que permitiam a êste último introduzir seiscentos negros todos os anos pelo Rio da Prata, os portuguêses levavam seus escravos até Potosi e com êles o resto...

Potosi domina a vida econômica da América do Sul nos séculos XVI e XVII. Sua atração foi bastante forte para ter modificado o eixo das vias de comunicação do continente: as estradas militares do Império incaica orientadas de norte a sul, acompanhando os dobramentos da cadeia, tornam-se secundárias. Os centros mineradores começam por animar o trajeto de Lima aos altiplanos; êles foram a causa da prosperidade do trecho Potosi-Buenos Aires pelo Rio da Prata. Erguendo-se no deserto que o amor pelo dinheiro transformou em uma cidade povoada e um mercado ativo, a Vila Imperial produziu por sua vez outro milagre: a rota transcontinental que unirá os dois Oceanos por sôbre uma das cadeias montanhosas mais altas e mais dificultosas do mundo. A vontade do homem estimulada pelo apetite de lucro criou a estrada a despeito das imperativos da geografia e do Rio da Prata. Seu traçado opunha mais do que unia Lima a Buenos Aires. Do longo antagonismo entre as duas cidades nasceu o espírito separatista que resultou, com a Independência, na criação de duas nações. Nesse caso ainda a economia determinou a política.

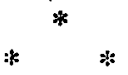

(37). - CARANDE (Ramón), Cartes de morcadores de Moneda y Credito n.0 9, 1944.

(38). - HARING (H. Clarence), Comercia y navedación entre España y las Indias en la época de los Habsburdas. México, 1939, p. 115

(39). - LOPEZ DE CARAVANTES (Francisco), Noticia dei Perí, man. Bibl. Pal. Real. 


\section{DOCUMENTO}

Archivo General de Simancas. - Secretarias Provinciales. Libro 1550. folio 320. En la carpeta. A Sua Magestade. Lixboa 1586.

Sobre as perssoas, que lhe pareçe que poderão seruir no cargo de Gouernador do Brazil.

E uisita que deue fazer o. Gobernador Manoel Tellez mas fortalezas daquelle estado.

E nauios darmada pera a costa delle.

E soldados que aly fuarom da armada de Diogo Flores.

E minas de Sanct Vinçente.

$\mathrm{E}$ caso do Yndio que naquellas partes se fez Papa.

E Fortaleza da Baya e fortes do Rio de Janeyro.

$\mathrm{E}$ residençcia que se deue tomar a Martim Leitão ouvidor geral.

E salitre que escreue o gobernador que se hauera no Brazil.

E nouo comerçio que se descubrio com a cydade de Buenos-Aires do Rio de Janeiro. - E prata que o Bispo de Tucumão mandou ao Gobernador, e mais cartas que fica uendo da quellas partes. $\mathrm{E}$ duas que manda, hua do ouvidor geral e outra do prouedor mor.

\section{Senhor,}

Tratando das pesoas que poderiao seruir a vosa magestade, no carego de gobernador do Brasil, e tornamdo despois a ver a materia por ser de muita consideraçao, me pareçeo que pera ysto se deuiao escolher pesoas de esperiencya e muyta comfiança, e as que se me oferrçerao sao Pero de Mendoça que foy vereador desta cydade e Dom Diogo de Llima que tambem 'foi vereador e fsta prouido da fortalerza de Ormuz e João de Saldanha que, o año pasado, foi as Ilhas por Capitão moor darmada e me pareçe que cada hum delles seruira bem neste a vosa magestade carego e particularmente. Pero de Mendoça.

Vi en comselho que por os nauios que ora chegarão do Brasil escriue a vosa magestade, o gohernador Manoel Dellez Barito (que serão com esta) a as materias que nellas trata e me par $\epsilon$ çeo que sera seruiço de vosa magestade mandarlhe escriuer que visite em pesoa todas as fortallizas daquell estado por aver muyto tempo que não são visitadas a aver queixas dos ministros da justiçia e fazenda que nella rresidem, dando che a tiempo e o estado das contas daquellas partes lugar pera o fazer.

E quanto aos nauios que pede para amderen darmada naquela costa per la muyta despesa que farão as duas galles que lhe forão mandadas fazer de que diz que he ferta hũa pera que pede negros do Cabo Verde pera a chusma della me pareçeo aver os nauios do porte que en sua carta diz e amdaren naquela costa darmada avemdo pesoa que os contrate que tambem poderão seruir de se leuarr nelles os provimentos que se podiren das outras fortallizas daquelas partes o que não poderam ser en galles por não ser capazes de poderr lleuar mantementos e não se pode nellas nauegar por aquela costa em todo o tempo do año e si sen de muyto efeito farão muyta despesa a fazemda de vosa magestade, e princypalmente avemdose de prouer de chusma de negros do Cabo Verde.

Tambem me pareçeo que sera seruiço de vosa magestade estarem com o gobernadoŕ os soldados que fícarão darmada de Diego Flores, posto que vosa ma gestade, lhe tenha mandado escriuer que os emuyase a Pararba, asi por las rrezoes que em sua carta apomta como por la enformação que ha de estar o forte de Pararba quieto. 
E sobre as materias das minas da capitania de Sam Viçemte semdo vosa magestade, seruido deue mandar tomar enformação dellas de hun Grauiel Soanz que a este Reino veyo con licenia do gobernador para adaar dellas e queriendo saber dell destas minas por que querendo aora saber delle, fui enformado que era hido a esa corte de Madrid pera com ella vosa magestade, mandar proçeder nesta materya como ouver por seu seruiço.

Que o gobernador trabelhe por aver a mão hum ymdio que naquelas partes se fez papa que escriue que depois de preso tornou a fugir e dissacreige de todo abusa pasada como comvem a importamcya deste caso e vosa magestade semdo seruido mande agradeçer as persoas que forão contra estes ymdios e bom modo comque nesto seruião a vosa magestade, e por capitulo separado na carta que mandar escriver ao mesmo gobernador.

Sobir a fortalliza que esta começada na Baya mando tomar enforção do sitio, grandura, e estado en que esta e o que podera custar e o modo que se tera en sua fortificação para com ella vosa magestade, a mandar prouer como foí mais seruido, e que depois de vir arreposta de Saluador Correa desa capitão do Rio de Janeiro; sera seruiço de vosa magestade, mandar tomar resolução nos fortes que dizen ser neçesario fazerse en aquela capitania.

E sera seruiço de vosa mags stade, mandar que o liçençiado Martin Lertão que ora serve de ouvydor geral naquelas partes e ha muitos dias que rreside en pernambuco se vaa a baya, pera nilla se tomar sua Residemcya.

Que o gobernador avise do perço en que se podera contratar o alletar que escriue que se fara naquelas partes posto ne bahia e a callidade delle pera conforme alho the vosa magestade, lhe mandar Responder ao que escriue sobre este particullar.

E asy me pareçe séruiço de vosa Magesłade, corer o comerçyo que se ora començou com os da cydade de Boynos-Ayres do Rio da Prata, e que se enuyem aquelas partes os padres da Companhia que dom Francisco de Vitoria, bispo de Tucumão, para naquele bispado aiudar a promulgar o evangミllio, e se escriua ao gobernador e ao visitador dos padres que residem naquelas partes os mande temdo. con ista cydade toda a boa correspomdemcya, e que vosa magestad? mande agredeçer a Saluador correa, capitão do Rio de Janeyro, ser o primeiro que abrio este caminho $\mathrm{E}$ que da prata que este bispo mandou ao gobernador lhe deue vosa magestade Hazer merçed como pede por the ser mandada na forma que vosa magestade mandara ver por sua carta, as mais cartas que daquelas partes são binidas vonbendo pera de todas dar enformação a vosa magestade, e nas materyas dellas, se proçeder na orden que vosa magestade for seruido e seräo, mais com esta, duas cartas, huan do ouvidor geral do Brasil e outra do prouedor da fazemda de vosa magestade, en Pernambuco de que me fição as copias. Noso Senhor, a muyto allta, e muy poderosa persoa de vosa magestade goarde e seu Real estado acreçente como dıseio e lhe peço. De Lizboa a XII de Julho de MDLXXXVI años.

Beisa as maos de vosa Magestade, seu muy humilde sobrinho, Do o Cardeal Archiduque a 12 de julho.

\section{MARIE HELMER}

Att. rech. du Centre National de la Recherche Scientifique (Paris). 


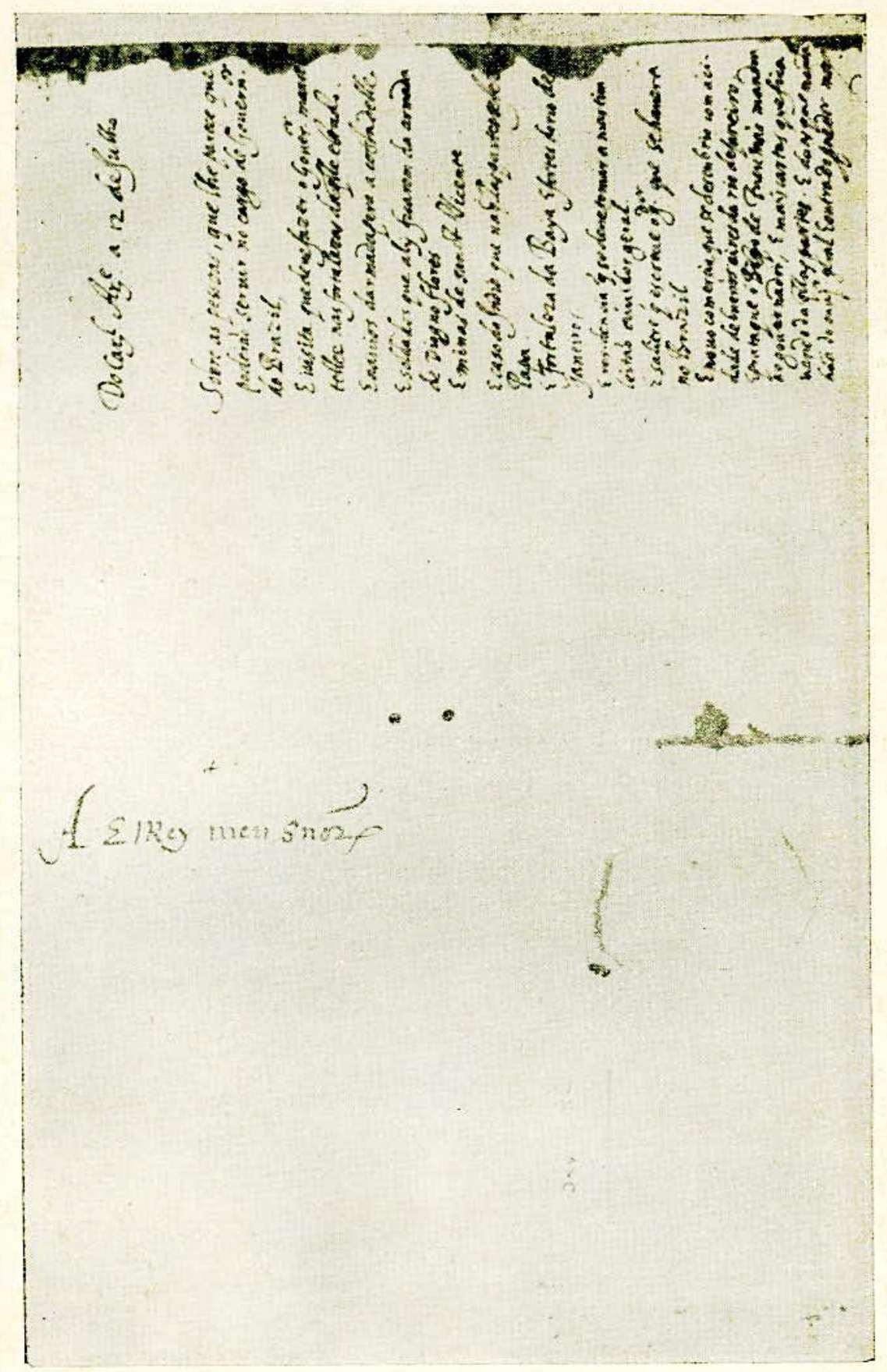




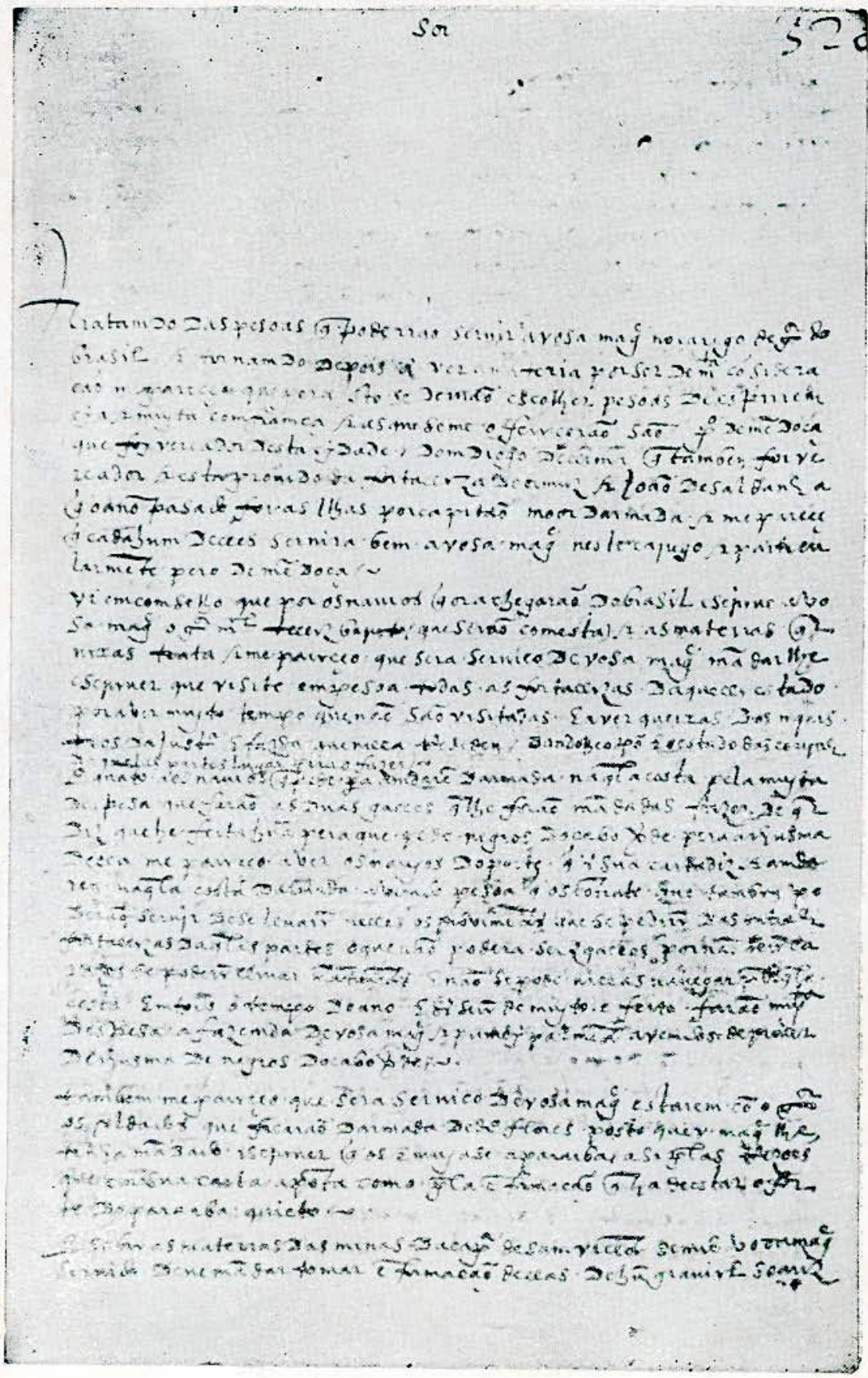




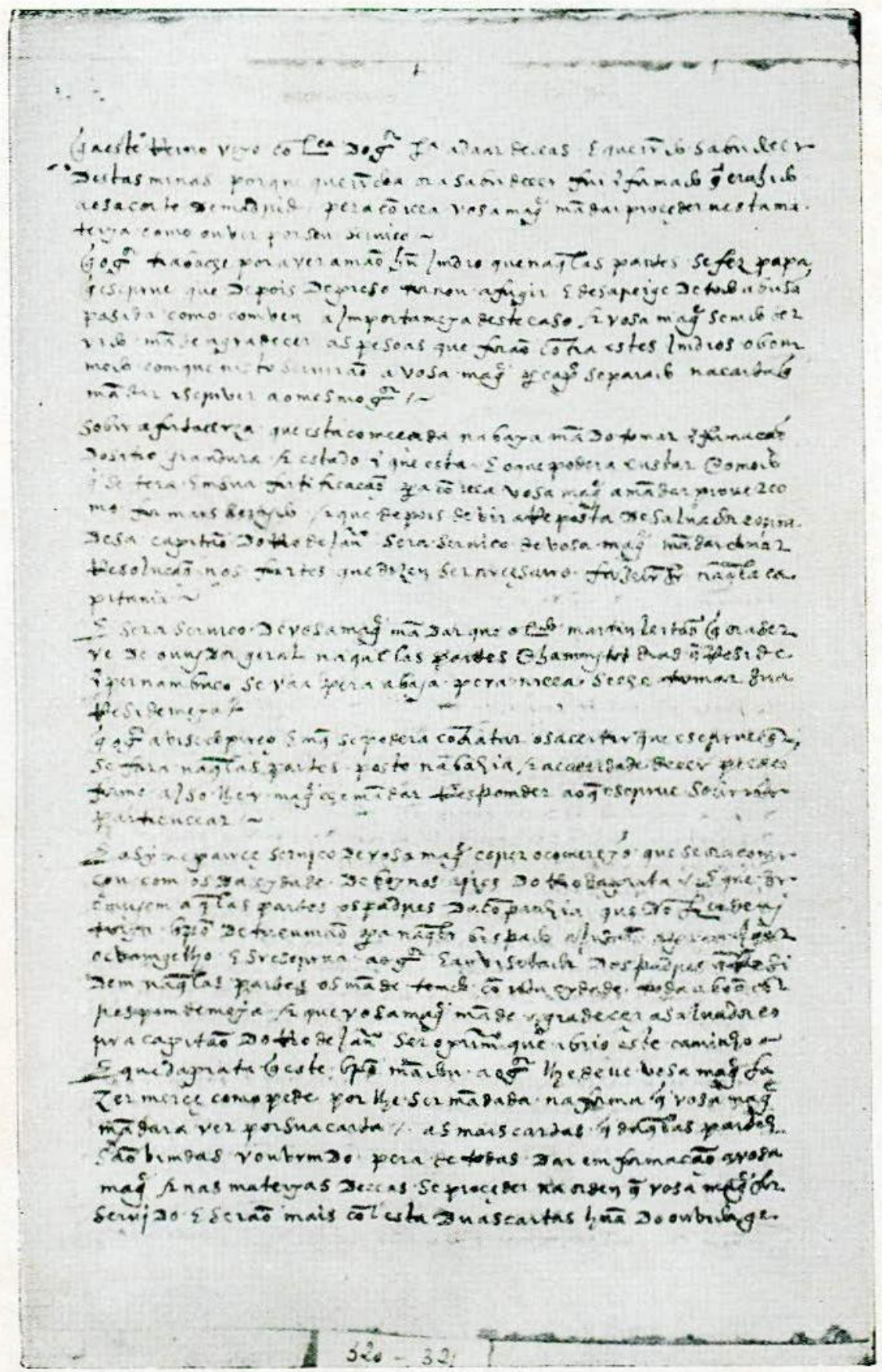




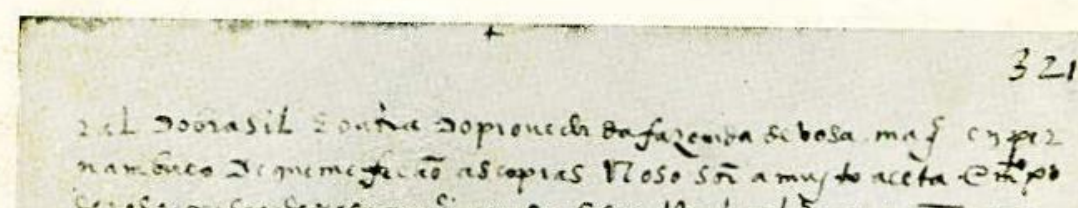

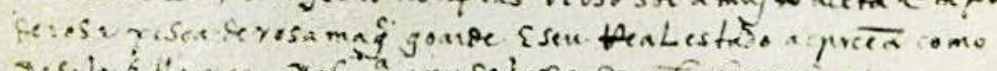

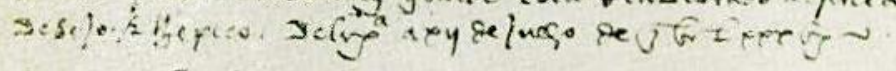

$\therefore \quad-2 . \because$

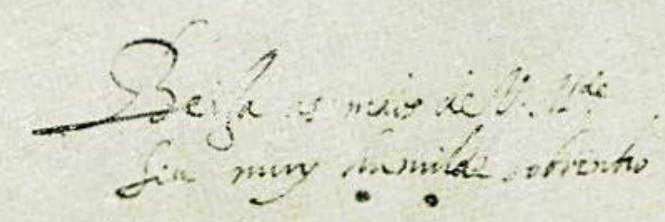

